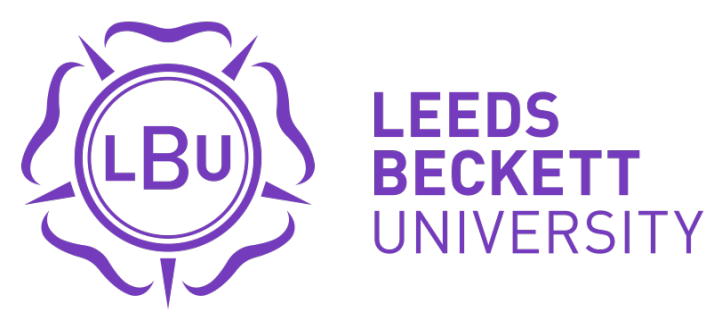

Citation:

Thomas, R and Ormerod, N (2017) Founts of knowledge or delusions of grandeur? Limits and illusions of tourism research impact: A reply to Wood. Tourism Management, 62. pp. 394-395. ISSN 0261-5177 DOI: https://doi.org/10.1016/j.tourman.2017.04.009

Link to Leeds Beckett Repository record:

https://eprints.leedsbeckett.ac.uk/id/eprint/3833/

Document Version:

Article (Accepted Version)

Creative Commons: Attribution-Noncommercial-No Derivative Works 4.0

The aim of the Leeds Beckett Repository is to provide open access to our research, as required by funder policies and permitted by publishers and copyright law.

The Leeds Beckett repository holds a wide range of publications, each of which has been checked for copyright and the relevant embargo period has been applied by the Research Services team.

We operate on a standard take-down policy. If you are the author or publisher of an output and you would like it removed from the repository, please contact us and we will investigate on a case-by-case basis.

Each thesis in the repository has been cleared where necessary by the author for third party copyright. If you would like a thesis to be removed from the repository or believe there is an issue with copyright, please contact us on openaccess@leedsbeckett.ac.uk and we will investigate on a case-by-case basis. 


\section{Founts of knowledge or delusions of grandeur? Limits and illusions of tourism research impact: a reply to $X$}

The starting point of our paper (Thomas and Ormerod, 2017) was to assess the extent to which academic research influenced policy and practice. Others have undertaken this task and come to a broadly similar conclusion; collectively, tourism researchers appear to have little impact on anyone other than fellow academics (and perhaps their students). Whether this is 'good' or bad', important or unimportant, depends on your perspective. In addition to illustrating the novel use of digital methods, the main contribution of our research lay in its attempt to explain why some academic researchers appear to have more non-academic impact than others. Our theorising of impact was, therefore, designed to identify variables that influenced impact and to show their interrelationships. Readers will reach their own conclusions about the extent to which we were successful in our ambition, but few will deny that we had a very comprehensive data set to work with, albeit limited to the UK.

The research was prompted by an international research policy environment that is becoming increasingly concerned with non-academic impact. A personal struggle to find suitable impact narratives to fulfil research council grant funding obligations provided added interest as did being commissioned to undertake several thought-provoking impact policy-related evaluation and consultancy projects by the UK's Economic and Social Research Council (ESRC). Perhaps the greatest impetus for the research, however, was a growing fascination with changing discourses in academia on the value of academic work and the increasing use by researchers of diverse methods, notably social media, to promote its usefulness to others. Impressive claims are now made routinely by some tourism academics about their influence; we wanted to 'test' such assertions and to establish a better understanding of the conditions under which impact occurs.

The growth of 'how to' books on impact (e.g. Denicolo, 2014; Reed, 2016) has not been matched by much critical assessment (e.g. Sayer, 2015). Our paper was intended to contribute to the latter. Although we share X's (2017) misgivings about the 'impact agenda' (see, for example, Thomas, 2011), we are less surprised by the manner in which academics respond to the increasingly neoliberal university settings they find themselves working in (Rustin, 2016). The evident intrinsic rewards and relative autonomy associated with much academic work does not, ultimately, offset the need to generate resources (in the form of pay) for personal and family sustenance; to secure their ability to pay bills, academics, are no less vulnerable to disciplinary actions, stymied careers or dismissal than any other worker if they refuse to respond to the priorities set by their managerial taskmasters. It seems somewhat glib, therefore, to expect individual academics to subvert and resist this pervasive policy priority in isolation. A collective response (as workers, presumably via trades unions, or as part of a campaign led by a subject association) would seem more likely to effect change but too few academics show an inclination for such coordinated acts of resistance. To that extent, academic researchers are perhaps, as $\mathrm{X}$ suggests, complicit in sustaining the focus on impact.

X (2017) makes important critical observations about the growing use of crude metrics to measure the value of academic work. Unless we are misreading aspects of his/her piece, the implication that we were proposing a new metric to measure impact is erroneous. That did not represent any part of our intellectual challenge and was not an outcome. His/her analysis of the processes of knowledge construction, and their implications to contemporary policy debates, are well made and add to a reasonably substantial body of literature (some of which is referred to in our paper). His/her 
refreshingly unfashionable re-emphasis on the promotion of research to enhance the education of students is particularly welcome. In our view, the academic 'game playing' spawned by official exhortations to 'make a difference' is damaging because it undermines a potentially more fruitful alternative activity, namely research to inform teaching. Efforts to share new knowledge with students who are immersed in an environment structured to facilitate learning, for short or long periods of time, is far more likely to result in socially desirable benefits (impact) from research and scholarship. The message to university managers is that researchers should spend more time in tutorials and less on tweeting or cultivating networks. For research policy-makers, our analysis implies rewarding those who are able to inculcate values and practices associated with ideas of lifelong learning rather than encouraging them to concentrate on self-promotion, 'noise' and, in most cases, exaggeration of impact.

\section{$\underline{\text { References }}$}

Denicolo, P. (Ed.) (2014). Achieving impact in research. London: Sage.

Reed, M.S. (2016). The research impact handbook. Aberdeenshire: Fast Track Impact.

Rustin, M. (2016). The neoliberal university and its alternatives. Soundings, 63: 147-176.

Sayer, D. (2015). Rank hypocrisies: The insult of the REF. London: Sage.

Thomas, $R$ (2011). Academics as policy-makers: (Not) researching tourism and events policy from the inside. Current Issues in Tourism, 14(6): 493-506.

Thomas, R. and Ormerod, N. (2017) The (almost) imperceptible impact of tourism research on policy and practice. Tourism Management 